\title{
IMPLEMENTASI IT DALAM MENGELOLA KEUANGAN UMKM UNTUK MENGALOKASIKAN ASET PERUSAHAAN DI KELURAHAN SUKAHURIP KECAMATAN TAMANSARI KOTA TASIKMALAYA
}

\section{IMPLEMENTATION OF IT IN MANAGING MSME FINANCES TO ALLOCATE COMPANY ASSETS IN SUKAHURIP VILLAGE, KECAMATAN TAMANSARI, TASIKMALAYA CITY}

\author{
Kusuma Agdhi Rahwana ${ }^{\# 1}$, Gea Aristi*2 \\ "Manajmen, Universitas Perjuangan Tasikmalaya \\ Jl. Peta No. 177 Kota Tasikmalaya \\ ${ }^{1}$ agdhikusuma@gmail.com \\ *Teknik Informatika, Universitas Perjuangan Tasikmalaya \\ Jl. Peta No. 177 Kota Tasikmalaya \\ ${ }^{2}$ geaaristiegmail.com
}

\begin{abstract}
Abstrak
Kelurahan Sukahurip adalah salah satu kelurahan di Kota Tasikmalaya yang penghasilan penduduknya didapat dari berwirausaha diantaranya yaitu kelom geulis, spon bahan alas sandal, tas, aneka makanan ringan, alat pera ga interaktif. Akan tetapi masyarakat tersebut masih perlu pembinaan dan pendampingan terutama dalam pengelolaan keuangan dikarenakan masih banyak masyarakat yang belum terlalu paham mengenai pengelolaan keuangan yang benar terutama pada pengalokasian aset perusahaan. Pada tahun pertama telah dilakukan pelatihan keuangan secara umum untuk meningkatkan pendapatan dan pelatihan keuangan dengan memanfaatkan IT yaitu dengan aplikasi excel. Akan tetapi selain pelatihan yang telah dilakukan pada tahun pertama diperlukan juga pelatihan managemen keuangan untuk mengalokasikan aset perusahaan. Selain itu diperlukan pelatihan pengelolaan pada segi laporannya dengan memanfaatkan aplikasi MYOB. Metode pelaksanaan adalah dengan cara pendekatan quality awareness, Metoda Rapid Rural Appraisal (RRA) untuk menyusun tindakan Pendampingan, Pelatihan, dan Pembinaan Metoda RRA digunakan untuk menyusun rencana tindak kesiapan masyarakat Kelurahan Sukahurip dalam menyongsong dan mengembangkan desa tersebut sebagai kawasan tujuan berbelanja, terutama rencana tindak yang berkaitan dengan bagaimana kelompok UMKM mengatasi masalah penentuan harga penjualan, pengelolaan keuangan.
\end{abstract}

Kata Kunci — Informasi, Keuangan, Pengelolaan, Teknologi.

Abstract

Sukahurip is one of the sub-districts in the City of Tasikmalaya whose residents' income is obtained from entrepreneurship, including geulis, sponges from sandals, bags, various snacks, interactive tools. However, these communities still need guidance and assistance, especially in financial management because there are still many people who do not really understand about proper financial management, especially in the allocation of company assets. In the first year, general financial training was conducted to increase income and financial training by utilizing IT, namely the excel application. However, in addition to the training that has been carried out in the first year, financial management training is also needed to allocate company assets. In addition, management training is needed in terms of reporting by using the MYOB application. The method of implementation is by means of a quality awareness approach, the Rapid Rural Appraisal (RRA) Method to formulate Mentoring, Training and Guidance actions The RRA method is used to compile an action plan for the readiness of the Sukahurip Village community in welcoming and developing the village as a shopping destination, especially an action plan. related to how the MSME group overcome the problem of determining sales prices, financial management.

Keywords - Information, Finance, Management, Technology.

\section{PENDAHULUAN}

Sukahurip adalah salah satu kelurahan di kecamatan Tamansari Kota Tasikmalaya. Luas kelurahan ini adalah 200 ha dengan jumlah penduduk 7600 orang. Sumber pendapatan masyarakat di kelurahan Sukahurip ini beragam, salah satunya adalah berwirausaha dari mulai usaha mikro, kecil, sampai menengah atau UMKM. Komoditas produk UMKM sangat variatif 
diantaranya adalah kelom geulis, spon bahan alas sandal, tas, aneka makanan ringan, dan alat peraga interaktif. Masyarakat di Desa tersebut mengatur kegiatan usahanya secara mandiri. Mulai dari operasional sampai dengan pengelolaan keuangan. Akan tetapi masyarakat tersebut masih perlu pembinaan dan pendampingan terutama dalam pengelolaan keuangan dikarenakan masih banyak masyarakat yang belum terlalu paham mengenai pengelolaan keuangan yang benar.

Pada tahun pertama telah dilakukan pelatihan keuangan secara umum untuk meningkatkan pendapatan dan pelatihan keuangan dengan memanfaatkan IT yaitu dengan aplikasi excel. Akan tetapi selain pelatihan yang telah dilakukan pada tahun pertama diperlukan juga pelatihan managemen keuangan untuk mengalokasikan aset perusahaan. Selain itu diperlukan pelatihan pengelolaan pada segi laporannya dengan memanfaatkan aplikasi MYOB.

Dengan demikian dengan adanya pelatihan keuangan untuk pengalokasian aset perusahaan maka para pelaku usaha UMKM selain mendapatkan ilmu tentang pengelolaan keuangan secara umum yang telah didapat pada tahun pertama, para pelaku UMKM pun akan mendapatkan ilmu baru tentang pengelolaan secara khusus. Selain itu dengan memanfaatkan aplikasi MYOB maka dapat menjadikan pengelolaan keuangan menjadi lebih efektif dan efisien.

Dari analisis situasi yang telah dipaparkan sebelumnya, maka dapat dirumuskan beberapa prioritas masalah yang harus diselesaikan, diantaranya:

1. Setelah dilakukan pelatihan pada tahun pertama

pelaku UMKM masih kesulitan dalam pengelolaan keuangan untuk pengalokasian aset perusahaan

2. Pelaku UMKM masih belum terbiasa dengan penggunaan aplikasi komputer

3. Pelaku UMKM menginginkan implementasi teknologi informasi yang lebih mudah dalam

penggunaannya untuk pengelolaan keuangan

Dari uraian di atas dan dari pengabdian yang telah

dilakukan pada tahun pertama, maka solusi yang disetujui sebagai solusi yang akan dilakukan pada kegiatan pengabdian ini adalah dengan melakukan pendampingan, pelatihan mengenai pengelolaan keuangan terutama pada pengalokasian aset perusahaan. Selain itu dilakukan juga pelatihan pengelolaan keuangan dengan memanfaatkan perkembangan teknologi yang ada dengan memanfaatkan aplikasi MYOB. Setiap tahun selama 3 tahun akan dilakukan pengelolaan keuangan yang berbeda tema. Pada tahun pertama dilakukan pelatihan pengelolaan keuangan secara umum dengan memanfaatkan aplikasi excel, pada tahun kedua akan dilakukan pelatihan keuangan untuk pengalokasian aset perusahaan dengan memanfaatkan aplikasi MYOB. Sedangkan pada tahun ketiga akan dibuat aplikasi untuk membantu dalam pengelolaan keuangan

Tujuan dari pengabdian ini adalah untuk:

1. Membantu masyarakat dalam mengelola keuangan

2. Membantu masyarakat dalam memaksimal hasil

yang diperoleh

3. Menumbuhkan kreativitas masyarakat dan

melakukan inovasi pengelolaan yang dihasilkan dengan mengikuti perkembangan IPTEK yang ada

4. Mendorong pertumbuhan pendapatan masyarakat

Kelurahan Sukahurip

Adapun manfaat yang dapat diperoleh dari pengabdian masyarakat ini adalah:

1. Meningkatkan pemahaman masyarakat terhadap pengelolaan keuangan

2. Memaksimalkan pendapatan yang mereka peroleh

3. Terciptanya masyarakat yang kreatif, inovatif dan

mengikuti perkembangan IPTEK

4. Meningkatkan kemampuan pelaku UMKM di Kelurahan Sukahurip dalam mengalokasikan asset Perusahaan

\section{METODE PELAKSANAAN}

Untuk mendukung tujuan, Tim dari Universitas Perjuangan akan melakukan pelatihan, pendampingan dan pembinaan berkaitan dengan pengelolaan keuangan terutama pengalokasian aset perusahaan yaitu:

1. Pendekatan quality awareness

Kualitas pelayanan merupakan faktor yang penting untuk dapat mendatangkan konsumen dan mempertahankan konsumen untuk kembali berbelanja. Tujuan aktivitas tersebut adalah memberikan pengetahuan kepada masyarakat tentang betapa pentingnya kualitas pelayanan yang akan diterima oleh para konsumen.

Kualitas pelayanan terkait dengan harga penjualan. Penentuan besarnya harga penjualan maka perhitungan unit cost diperlukan. Pentingnya adalah mengetahui besarnya biaya yang benar-benar dibutuhkan untuk menghasilkan harga jual konsumen serta disamping faktor kemampuan dan kemauan membayar dari masyarakat. Implikasi harga produksi adalah dasar penetapan harga jual serta menentukan kebijakan cara penjualan produk bila diperlukan perluasan. Kebijakan ini diperlukan untuk menghindari persaingan yang tidak sehat. 
Bentuk dari quality awareness adalah sosialisasi pengelolaan keuangan dan workshop, serta melibatkan aparat pemerintahan setempat untuk mengorganisasi semua penduduk yang memiliki fasilitas-fasilitas komersial.

2. Metoda Rapid Rural Appraisal (RRA) untuk menyusun tindakan Pendampingan, Pelatihan, dan Pembinaan

Metoda penyusunan data dan rencana pengembangan

Rapid Rural Appraisal (RRA). Rapid Rural

Appraisal (RRA) merupakan suatu kegiatan sistematik dan terstruktur yang dilakukan oleh peneliti atau tenaga ahli dari berbagai disiplin dengan tujuan mengumpulkan informasi dan data secara cepat dan efisien tentang fenomena kehidupan dan sumberdaya masyarakat di pedesaan. RRA memfokuskan pada upaya dan peran yang lebih besar kepada tim peneliti (expert) untuk melakukan pengkajian secara mendalam. Masyarakat cenderung ditempatkan sebagai objek kajian yang akan menjadi bahan bagi tim untuk menyusun asumsi, deskripsi dan kerangka tindakan. Metoda RRA digunakan untuk menyusun rencana tindak

kesiapan masyarakat Kelurahan Sukahurip dalam menyongsong dan mengembangkan desa tersebut sebagai kawasan tujuan berbelanja, terutama rencana tindak yang berkaitan dengan bagaimana kelompok UMKM mengatasi masalah penentuan harga penjualan, pengelolaan keuangan dan akuntansi. Kegiatan tersebut meliputi pelatihan dan pendampingan pengelolaan keuangan berbagai UMKM di Kelurahan Sukahurip sejak produksi, menjual barang sampai konsumen meninggalkan Kelurahan Sukahurip.

RRA akan dihasilkan rencana tindak pemberdayaan UMKM yang dilanjutkan dalam pendampingan sebagai berikut:

1. Melakukan pendampingan dan pembinaan dalam pengelolaan keuangan UMKM

2. Melakukan pendampingan dalam penyusunan modal kerja yang likuid dalam bisnis UMKM

3. Melakukan pendampingan dan pembinaan dalam proses penyusunan laporan perencanaan keuangan dan modal kerja UMKM

Usulan program pelatihan, pembinaan dan pendampingan proses pengelolaan UMKM Kelurahan Sukahurip berbasis IT akan digunakan sebagai dasar pelaksanaan pengelolaan keuangan UMKM Adapun hasil dari proses tersebut adalah Terciptanya pengelolaan keuangan yang akuntabel.

\section{TARGET DAN LUARAN}

Target dan luaran dari kegiatan pengabdian ini mengacu pada permasalahan yang mana membutuhkan

sekali pelatihan dalam pengalokasian aset perusahaan dan pemanfaatan aplikasi komputer untuk mendukung pengelolaan tersebut.

Pada tahun kedua ini dilakukan pelatihan tentang pengelolaan keuangan dengan mengkhususkan pada pengalokasian aset perusahaan dan dilakukan pula pelatihan dengan menggunakan MYOB untuk membantu pengelolaan tersebut. Luaran dari pengabdian ini adalah berupa jurnal yang akan diterbitkan di Jurnal Ekonomi Universitas Perjuangan. Dengan ISSN 2549-872X. Selain itu dibuat bahan ajar untuk mata kuliah manajemen keuangan dan aplikasi komputer Tabel.

Target dan luaran yang akan dilaksanakan :

\begin{tabular}{|c|c|c|c|c|}
\hline $\mathrm{N}$ & $\begin{array}{c}\text { Permasalah } \\
\text { an }\end{array}$ & Solusi & Target & Luaran \\
\hline 1 & $\begin{array}{l}\text { Kesulitan } \\
\text { dalam } \\
\text { pengalokas } \\
\text { ian asset } \\
\text { perusahaan }\end{array}$ & $\begin{array}{l}\text { Dilakukan } \\
\text { pelatihan } \\
\text { pengalokas } \\
\text { ian } \\
\text { asset } \\
\text { perusahaan }\end{array}$ & $\begin{array}{l}\text { Pelaku } \\
\text { UMKM } \\
\text { memahami } \\
\text { pengalokas } \\
\text { ian asset } \\
\text { perusahaan }\end{array}$ & $\begin{array}{l}\text { Berhasil } \\
\text { mengalokasi } \\
\text { kan asset } \\
\text { perusahaan }\end{array}$ \\
\hline 2 & $\begin{array}{l}\text { Masih } \\
\text { belum } \\
\text { terbiasa } \\
\text { dalam } \\
\text { memanfaat } \\
\text { kan } \\
\text { teknologi } \\
\text { informasi }\end{array}$ & $\begin{array}{l}\text { Dilakukan } \\
\text { pelatihan } \\
\text { dengan } \\
\text { memanfaat } \\
\text { kan } \\
\text { aplikasi } \\
\text { MYOB }\end{array}$ & $\begin{array}{l}\text { Pelaku } \\
\text { UMKM } \\
\text { memahami } \\
\text { pemanfaat } \\
\text { an aplikasi } \\
\text { MYOB }\end{array}$ & $\begin{array}{l}\text { Kemampuan } \\
\text { Pelaku } \\
\text { UMKM } \\
\text { memanfaatk } \\
\text { an aplikasi } \\
\text { MYOB }\end{array}$ \\
\hline 3 & $\begin{array}{l}\text { Belum } \\
\text { memahami } \\
\text { pengelolaa } \\
\text { n keuangan } \\
\text { yang benar }\end{array}$ & $\begin{array}{l}\text { Dilakukan } \\
\text { pendampin } \\
\text { gan dalam } \\
\text { pengelolaa } \\
\text { n keuangan } \\
\text { dan } \\
\text { pemanfaata } \\
\text { n teknologi } \\
\text { yang ada }\end{array}$ & $\begin{array}{l}\text { Pelaku } \\
\text { UMKM } \\
\text { terampil } \\
\text { mengguna } \\
\text { kan } \\
\text { computer } \\
\text { dan } \\
\text { teknologi } \\
\text { internet }\end{array}$ & $\begin{array}{l}\text { Meningkatn } \\
\text { ya } \\
\text { kemampuan } \\
\text { pelaku } \\
\text { UMKM } \\
\text { dalam } \\
\text { menggunaka } \mathrm{n} \\
\text { teknologi TI } \\
\text { untuk } \\
\text { mendukun g } \\
\text { pengelolaa } \mathrm{n} \\
\text { keuangan }\end{array}$ \\
\hline
\end{tabular}


Rencana target capaian dari dilakukannya pengabdian masyarakat dengan melakukan pelatihan di Kelurahan Sukahurip ini adalah:

\begin{tabular}{|c|c|c|c|}
\hline $\mathbf{N}$ & \multicolumn{2}{|l|}{ Jenis Luaran } & Indikator \\
\hline 1 & \multicolumn{2}{|c|}{$\begin{array}{l}\text { Publikasi ilmiah di jurnal } \\
\text { nasional }\end{array}$} & Draft \\
\hline \multirow[t]{2}{*}{2} & \multirow[t]{2}{*}{$\begin{array}{l}\text { Pemakalah dalam } \\
\text { Temu Ilmiah }\end{array}$} & Nasional & Draft \\
\hline & & Lokal & Sudah terlaksana \\
\hline \multirow[t]{2}{*}{3} & \multirow[t]{2}{*}{ BahanAjar } & Handout & Draft \\
\hline & & Buku Ajar & - \\
\hline 4 & \multirow{2}{*}{\multicolumn{2}{|c|}{$\begin{array}{l}\text { Teknologi Tepat } \\
\text { Guna,Model / } \\
\text { Purwarupa/ } \\
\text { Potensi } \\
\text { HaKI/ } \\
\text { Paten }\end{array}$}} & - \\
\hline 5 & & & - \\
\hline
\end{tabular}

\section{METODE PELAKSANAAN}

Untuk mendukung tujuan, Tim dari Universitas

Perjuangan akan melakukan pelatihan, pendampingan dan pembinaan berkaitan dengan pengelolaan keuangan terutama pengalokasian aset perusahaan yaitu:

Pendekatan quality awareness

Kualitas pelayanan merupakan faktor yang penting untuk dapat mendatangkan konsumen dan mempertahankan konsumen untuk kembali berbelanja. Tujuan aktivitas tersebut adalah memberikan pengetahuan kepada masyarakat tentang betapa pentingnya kualitas pelayanan yang akan diterima oleh para konsumen.

Kualitas pelayanan terkait dengan harga penjualan. Penentuan besarnya harga penjualan maka perhitungan unit cost diperlukan. Pentingnya adalah mengetahui besarnya biaya yang benar-benar dibutuhkan untuk menghasilkan harga jual konsumen serta disamping faktor kemampuan dan kemauan membayar dari masyarakat. Implikasi harga produksi adalah dasar penetapan harga jual serta menentukan kebijakan cara penjualan produk bila diperlukan perluasan. Kebijakan ini diperlukan untuk menghindari persaingan yang tidak sehat. Bentuk dari quality awareness adalah sosialisasi pengelolaan keuangan dan workshop, serta melibatkan aparat pemerintahan setempat untuk mengorganisasi semua penduduk yang memiliki fasilitas-fasilitas komersial.

2. Metoda Rapid Rural Appraisal (RRA) untuk menyusun tindakan Pendampingan, Pelatihan, dan Pembinaan Metoda penyusunan data dan rencana pengembangan Rapid Rural Appraisal (RRA). Rapid Rural Appraisal (RRA) merupakan suatu kegiatan sistematik dan terstruktur yang dilakukan oleh peneliti atau tenaga ahli dari berbagai disiplin dengan tujuan mengumpulkan informasi dan data secara cepat dan efisien tentang fenomena kehidupan dan sumberdaya masyarakat di pedesaan. RRA memfokuskan pada upaya dan peran yang lebih besar kepada tim peneliti (expert) untuk melakukan pengkajian secara mendalam. Masyarakat cenderung ditempatkan sebagai objek kajian yang akan menjadi bahan bagi tim untuk menyusun asumsi, deskripsi dan kerangka tindakan Metoda RRA digunakan untuk menyusun rencana tindak kesiapan masyarakat Kelurahan Sukahurip dalam menyongsong dan mengembangkan desa tersebut sebagai kawasan tujuan berbelanja, terutama rencana tindak yang berkaitan dengan bagaimana kelompok UMKM mengatasi masalah penentuan harga penjualan, pengelolaan keuangan dan akuntansi. Kegiatan tersebut meliputi pelatihan dan pendampingan pengelolaan keuangan berbagai UMKM di Kelurahan Sukahurip sejak produksi, menjual barang sampai konsumen meninggalkan Kelurahan Sukahurip. RRA akan dihasilkan rencana tindak pemberdayaan UMKM yang dilanjutkan dalam pendampingan sebagai berikut: 1. Melakukan pendampingan dan pembinaan dalam pengelolaan keuangan UMKM $2 . \quad$ Melakukan

pendampingan dalam penyusunan modal kerja yang likuid dalam bisnis UMKM 3. Melakukan pendampingan dan pembinaan dalam proses penyusunan laporan perencanaan keuangan dan modal kerja UMKM Usulan program pelatihan, pembinaan dan pendampingan proses pengelolaan UMKM Kelurahan Sukahurip berbasis IT akan digunakan sebagai dasar pelaksanaan pengelolaan keuangan UMKM Adapun hasil dari proses tersebut adalah Terciptanya pengelolaan keuangan yang akuntabel IV. HASIL DAN PEMBAHASAN Target dan luaran dari kegiatan pengabdian ini mengacu pada permasalahan yang mana membutuhkan sekali pelatihan dalam pengelolaan keuangan terutama pelatihan yang memanfaatkan teknologi informasi yang ada agar bisa memaksimalkan pertumbuhan pendapatan masyarakat di Kelurahan Sukahurip. Nantinya akan dilakukan pelatihan tentang pengelolaan keuangan dan dilakukan pula pelatihan dengan menggunakan MYOB untuk memudahkan pengelolaan keuangan. Luaran dari pengabdian ini adalah berupa jurnal yang akan diterbitkan di lingkungan Universitas Perjuangan. Selain itu dibuat bahan ajar untuk mata kuliah manajemen keuangan dan aplikasi komputer. Target dan luaran yang akan dilaksanakan adalah sebagai Berikut 


\begin{tabular}{|c|c|c|c|c|c|c|}
\hline No & Materi & Tujuan & Metode/Med ia & Peserta & Tempat & Waktu \\
\hline 1 & Diskusi Pengab dian & $\begin{array}{l}\text { Dapat menget ahui } \\
\text { Tempat dan tujuan } \\
\text { pengab dian }\end{array}$ & Diskusi interak tif & $\begin{array}{c}\text { Ketua dan anggot } \\
\mathrm{a}\end{array}$ & Kampus & 26Juni 2018 \\
\hline 2 & $\begin{array}{c}\text { Kunjungan ke } \\
\text { Kelura han Sukahu } \\
\text { rip }\end{array}$ & $\begin{array}{c}\text { Membe rikan surat } \\
\text { pengant ar }\end{array}$ & Diskus i interaktif & $\begin{array}{l}\text { Ketua dan } \\
\text { anggota, } \\
\text { lurah }\end{array}$ & $\begin{array}{l}\text { Kelurahan } \\
\text { Sukahurip }\end{array}$ & 27Juni 2018 \\
\hline 3 & $\begin{array}{c}\text { Kunjungan ke } \\
\text { Kelurahan } \\
\text { Sukahurip }\end{array}$ & $\begin{array}{l}\text { Menga mbil surat } \\
\text { pengantar dan } \\
\text { mendis kusikan } \\
\text { materi pelatihan }\end{array}$ & Diskusi interak tif & $\begin{array}{l}\text { Ketua dan } \\
\text { anggota, } \\
\text { lurah }\end{array}$ & $\begin{array}{l}\text { Kelurahan } \\
\text { Sukahurip }\end{array}$ & 28 Juni 2018 \\
\hline 4 & $\begin{array}{l}\text { Diskusi materi } \\
\text { pelatihan }\end{array}$ & $\begin{array}{c}\text { Menget ahui materi } \\
\text { pelatiha } n \text { yang } \\
\text { akan diberik an }\end{array}$ & Diskusi interak tif & Ketua dan anggota & RumahMakan & 3 n Juli 2018 \\
\hline 5 & $\begin{array}{c}\text { Pelatih an Pengel } \\
\text { olaan Keuang an } \\
\text { Untuk UMKM oleh } \\
\text { Kusum a Agdhi, } \\
\text { MM }\end{array}$ & $\begin{array}{c}\text { Menget ahui Pengel } \\
\text { olaan keuang an } \\
\text { Untuk UMKM }\end{array}$ & $\begin{array}{c}\text { Presentasi Disku i } \\
\text { Interaktif }\end{array}$ & Anggota UMKM & $\begin{array}{l}\text { Kelurahan } \\
\text { Sukahurip }\end{array}$ & 5 Juli 2018 \\
\hline 6 & $\begin{array}{c}\text { Pelatihan } \\
\text { Pengelolaan } \\
\text { Keuangan dengan } \\
\text { meman faatkan } \\
\text { aplikasi MYOB }\end{array}$ & $\begin{array}{c}\text { Mengetahui pemanf } \\
\text { aatanapliksai } \\
\text { MYOB untuk } \\
\text { mengeola keuang an }\end{array}$ & $\begin{array}{l}\text { Presentasi } \\
\text { Diskusi } \\
\text { Interaktif }\end{array}$ & Anggota UMKM & $\begin{array}{l}\text { Kelurahan } \\
\text { Sukahurip }\end{array}$ & $\begin{array}{l}16 \text { Agustus } \\
2018\end{array}$ \\
\hline 7 & $\begin{array}{c}\text { Pelatih an } \\
\text { Pengel olaan } \\
\text { Keuang an } \\
\text { dengan meman } \\
\text { faatkan aplikasi } \\
\text { MYOB }\end{array}$ & $\begin{array}{c}\text { Menget ahui } \\
\text { pemanf aatan } \\
\text { apliksai } \\
\text { MYOB } \\
\text { untuk mengel ola } \\
\text { keuangan }\end{array}$ & $\begin{array}{l}\text { Pre sent asi } \\
\text { Dis kus i } \\
\text { Inte rakt } \\
\quad \text { if }\end{array}$ & $\begin{array}{l}\text { Anggo ta } \\
\text { UMK M }\end{array}$ & $\begin{array}{l}\text { Kelura han } \\
\text { Sukahu rip }\end{array}$ & $\begin{array}{c}12 \text { September } \\
2018\end{array}$ \\
\hline 8 & $\begin{array}{c}\text { Membuat } \\
\text { laporan kemajuan }\end{array}$ & $\begin{array}{c}\text { Membuat } \\
\text { laporan kemajuan }\end{array}$ & $\begin{array}{l}\text { Dis kus i } \\
\text { inte raktif }\end{array}$ & $\begin{array}{l}\text { Ketua dan } \\
\text { anggota }\end{array}$ & $\begin{array}{l}\text { Rumah } \\
\text { Makan }\end{array}$ & $\begin{array}{c}7 \text { Novem er } \\
2018\end{array}$ \\
\hline
\end{tabular}

Program ini di laksanakan sebagai implementasi dari tri dharma perguruan tinggi bidang pengabdian masyarakat, Universitas Perjuangan. Kegiatan ini dilaksanakan mulai bulan Juni sampai Bulan November 2018 III. KESIMPULAN Berdasarkan pengabdian yang telah dilakukan maka dapat diperoleh: 1. Berdasarkan hasil pengabdian yang telah dilakukan maka dapat dianalisa para pelaku UMKM sebagian besar masih belum mengetahui pengelolaan keuangan yang benar. 2 . Berdasarkan hasil pengabdian yang telah dilakukan maka dapat dianalisa para pelaku UMKM sebagian besar masih mengelola keuangan secara manual dan sederhana 3. Berdasarkan hasil pengabdian yang telah dilakukan maka dapat dianalisa para pelaku UMKM sebagian besar masih belum mengetahui pemanfaatan teknologi informasi untuk membantu pengelolaan keuangan 4. Berdasarkan hasil pengabdian yang telah dilakukan maka dengan pelatihan pengelolaan keuangan pelaku UMKM merasa terbantu dalam mengelola keuangan 5 . Berdasarkan hasil pengabdian yang telah dilakukan maka dengan pelatihan pemanfaatan aplikasi MYOB dapat memudahkan para pelaku UMKM untuk mengelola keuangan

\section{UCAPAN TERIMA KASIH}

Terimakasih kepada Lembaga Penelitian dan Pengabdian Masyarakat (LP2M) Universitas Perjuangan Tasikmalaya adanya program Hibah Internal yang telah mendanai kegiatan PTTG tahun 2018, Lurah dan kelompok UMKM Kelurahan Sukahurip Kecamatan Tamansari Kota Tasikmalaya. 


\section{DAFTAR PUSTAKA}

[1] Suad Husnan dan Enny Pudjiastuti, "Dasar-dasar Manajemen Keuangan”, UPP AMP YKPN, 2004

[2] Danang Sunyoto, Dasar-dasar Manajemen Keuangan Perusahaan", Caps Publishing, 2013

[3] Kotler, Philip. 2007. Manajemen Pemasaran Indonesia.Buku 2. Jakarta: Salemba Empat.

[4] Kelurahan Sukahurip Kecamatan Tamansari Kota Tasikmalaya. 